\title{
Does Perceived Organizational Support Mitigate the Negative Effect of Teacher- Researcher Role Conflict among Lecturers? (Evidence from Indonesia)
}

\author{
Mohamad Arief Rafsanjani ${ }^{1}$, Muhammad Abdul Ghofur ${ }^{2}$, Dhiah Fitrayati ${ }^{3}$, \\ Retno Mustika Dewi ${ }^{4}$ \\ ${ }^{1}$ Universitas Negeri Surabaya, Faculty of Economics, Jl. Ketintang, Surabaya, Indonesia, mohamadrafsanjani@unesa.ac.id \\ ${ }^{2}$ Universitas Negeri Surabaya, Faculty of Economics, Jl. Ketintang, Surabaya, Indonesia, muhammadghofur@unesa.ac.id \\ ${ }^{3}$ Universitas Negeri Surabaya, Faculty of Economics, Jl. Ketintang, Surabaya, Indonesia, dhiahfitrayati@unesa.ac.id \\ ${ }^{4}$ Universitas Negeri Surabaya, Faculty of Economics, Jl. Ketintang, Surabaya, Indonesia, retnomustika@unesa.ac.id
}

\begin{abstract}
This study investigated the role of perceived organizational support (POS) as a moderating variable in reducing the negative effect of teacher-researcher role conflict on psychological well-being (work enthusiasm and emotional exhaustion). Participants were 233 lecturers from 19 universities in Indonesia. The study found that teaching-research role conflict was negatively related to psychological well-being, POS was a significant moderating variable in this model, it reduced the negative effect of teacher-researcher role conflict on psychological well-being.
\end{abstract}

Keywords: perceived organizational support, teacher-researcher role conflict, psychological well-being, lecturer.

\section{Introduction}

As we know, the lecturer is a profession that burdened by two different roles or tasks that have to conducted simultaneously as a teacher and researcher. On the one hand, as a teacher, it's related to teaching activity, the activity related to the profession of those who give instruction, especially in an elementary, secondary, or higher education (Havighurst, 2018). On the other hand, as a researcher, the lecturer had to conduct research 
such as developing and examining theories, verifying data, and conducting experiments (Xu, 2017).

Teaching and research are unseparated roles of the lecturer. Its reciprocal activities of a lecturer to keep in pace with the science development (Jencks \& Riesman, 1968). Furthermore, conducting research give great benefits for a lecturer related to their duties (Kingman, 1993), because making research as a basis of instruction is needed in higher education. But, the dual role makes excessive workload to the lecturer is high.

Teaching and conducting research at the same time is the job demands of the lecturer profession. Still, some literature states it is hard to do these roles, as a teacher and researcher, simultaneously. In the Scarcity Model (Moore, 1963), the Personality Model (Eble, 1976) and the Divergent Rewards Model (Ladd, 1979). The three models state that doing too much role or task at the same time or the same job has a high possibility of experiencing role conflict because of a deficiency of time and energy. Each role or task had not only different characteristics that require different characters (personalities), but also had different reward schemes, in the end, it drives a lecturer to more focus on one role and less attention to the others as consequences.

In the job demands-resources (JDR) model, job demands related to work targets, work pressure, and everything both physically and psychologically required in a job. Moreover, job resources related to the tools used by employees to reduce job demands such as job facilities, career paths, and colleagues' support (Demerouti, Bakker, Nachreiner, \& Schaufeli, 2001). Thus the dual role that experienced by the lecturer is part of job demands.

Previous studies found the higher the role conflict experienced by the lecturer, the lower the psychological well-being of the lecturer (Cao, Shang, \& Meng, 2020; Xu, 2017). Moreover, $60 \%$ of burnout mostly explained by role conflict (Xu, 2017). Besides, psychological well-being takes an essential role in the learning and instruction due to related to the work enthusiasm and emotional exhaustion of the lecturer (Arens \& Morin, 2016; Klusmann, Kunter, Trautwein, Lüdtke, \& Baumert, 2008). These show us the significant effect of role conflict on psychological well-being and drive us to have more concern about the role conflict that experienced by the lecturer due to the negative effect, and how to mitigate this negative effect.

As indicated by the JDR model, job resources will mitigate the negative impact of job demands on the well-being of employees caused by excessive job demands. Several previous studies have focused on the mitigating effects of job resources on job demands partially such as self-efficacy, optimism, job autonomy, and time control (Fernet, Austin, Trépanier, \& Dussault, 2013; Llorens, Schaufeli, Bakker, \& Salanova, 2007; Xanthopoulou, Bakker, Demerouti, \& Schaufeli, 2007). But, how the job resources process reduces the negative impact of the job demands, teacher-researcher role conflict on psychological well-being, has never been directly examined.

One of the job resources that play an essential role in reducing the negative impact of job demands is perceived organizational support (POS) (Rhoades \& Eisenberger, 2002). 
POS is the employees' perception of how the organization values employee contributions and how the organization cares about the psychological well-being of the employee (Eisenberger, Fasolo, \& Davis-LaMastro, 1990). Previous studies found that POS act as a job resource in reducing the negative impact of role conflict. Unfortunately, no study has tested how the role of POS in reducing the negative effects of the teacher-researcher role conflict (job demands) on psychological well-being. So, this study poses the role of POS as a moderating variable in the link between teacher-researcher role conflict and psychological well-being.

\section{Theoretical Framework}

\section{Teacher-researcher role conflict and psychological well-being}

Being a teacher on higher education means ready to face the dual role profession as a teacher and researcher. It means the lecturer can not only teach well but also must conduct well research simultaneously (Xu, 2017). The dual roles that must be undertaken by lecturers make excessive workload due to a deficiency of time and energy. So it makes lecturers more vulnerable to experiencing role conflict. Moreover, at least three models explain that it is difficult to carry out more than one role or task in the same work optimally. It's lead the lecturer to experience the role conflict.

In the scarcity model (Moore, 1963), too many roles or tasks in the same job lead someone to the high possibility of role conflict because of a lack of energy and time. It's led to focuses on one role and less attention to the others as a consequence. In line with, the divergent rewards model (Ladd, 1979) found that teaching and research have different reward schemes, then drive the employee to focus more on the activity or role that gives a higher return. It means there is a role or task that will be neglect as a consequence. In the personality model (Eble, 1976), teaching and research are jobs with different characteristics; thus, they require different characters. Researchers need a lot of time of less distraction to focus, and it will be helpful to working alone. At the same time, the teachers have to communicate and interact with students and have a high possibility to be more distracted.

The three models indicate that it is hard being a teacher and a researcher at once. The demands to carry out all roles in the optimum lead the lecturer has a high possibility to experienced role conflict due to excessive workload. According to the JDR model (Demerouti et al., 2001), the excessive workload will drain the energy and strain that caused stress to the employee. Then it has a negative effect on psychological well-being. Previous studies show that job demands highly related to psychological well-being (Bakker, Demerouti, \& Euwema, 2005; Hakanen, Bakker, \& Schaufeli, 2006; Rafsanjani, Pamungkas, \& Rahmawati, 2019; van den Tooren \& de Jong, 2014). 
Psychological well-being refers to the optimum condition of psychological and work experience (Ryan \& Deci, 2001). Its seen from the work enthusiasm and emotional exhaustion (Aldrup, Klusmann, \& Lüdtke, 2017; Rafsanjani \& Rahmawati, 2019). The optimum condition of psychological and work experience marked by positive things that are felt, e.g., work enthusiasm and job satisfaction, and the non-appearance of the negative, e. g., emotional exhaustion and stress (Diener, Suh, Lucas, \& Smith, 1999; Kunter et al., 2008; Watson, Clark, \& Tellegen, 1988).

Work enthusiasm is the feeling of enjoyment and excitement related to the job and reflected the more engage or more involve in a job or task (Kunter et al., 2008). Meanwhile, emotional exhaustion refers to the negative emotion and fatigue due to job demands. It's reflected in the physical fatigue and the lowest point of psychological and emotional condition (Wright \& Cropanzano, 1998).

In sum, the job demands of the lecturer, being a teacher and researcher at once, lead to the role conflict experienced. This research used the role of conflict as a predictor of the psychological well-being of the lecturer.

\section{The mitigating effect of perceived organizational support (POS)}

As we mentioned earlier in the JDR model, job resources will interact with and reduce the negative effect of job demands. Previous research shows that perceived organizational support (POS) is one of job resources. POS related to the perception of the employee on how the organization or workplace values the employee contributions and cares about the psychological well-being of the employee (Eisenberger et al., 1990).

The previous finding shows that employees' POS positively related to job responsibilities, expressed emotional, organizational, and job engagement and their innovation without direct reward or individual acknowledgment (Eisenberger et al., 1990). Some studies show when the employees felt greater support from the organization, they are easier to deal with distress or strain and tend to be more committed to the job (Casper, Martin, Buffardi, \& Erdwins, 2002; Parasuraman, Greenhaus, \& Granrose, 1992). Besides, POS leads to the positive work attitude and performance (Rhoades \& Eisenberger, 2002), mental health (Hao, Wang, Liu, Wu, \& Wu, 2016), and also lessen the effect of role conflict on work outcomes (Huang, Fan, \& Fu, 2007). It's proven that POS seems to act as a job resource and reducing the negative effect of role conflict.

Therefore, it's reasonable if the POS acts as job resources that could reduce the negative effect of teacher-researcher role conflict. POS is increasing the lecturer's belief that they cared for and helped by the university, and its worthy of giving high effort due to dual role, as a teacher and researcher, to get more in the future. Finally, it will reduce emotional exhaustion and raise work enthusiasm.

The previous studies show that POS acts as job resources then reduces the negative effect of role conflict (Casper et al., 2002; Parasuraman et al., 1992; Rhoades \& Eisenberger, 2002; Vigoda-Gadot \& Meisler, 2010). But, how the role of POS in reducing the 
negative effects of the teacher-researcher role conflict (job demands) on psychological well-being is not clear. So, the present study tries to put the POS as a moderating variable to explain how the role of the POS in reducing the negative impact of the role of conflict on psychological well-being.

Based on the theories, the research hypotheses are:

H1. The teacher-researcher role conflict has a negative effect on the psychological wellbeing of lecturers (reduce work enthusiasm and increase emotional exhaustion).

H2. Perceived organizational support play as moderating variable in mitigating the negative effect of teacher-researcher role conflict on the psychological well-being of lecturers.

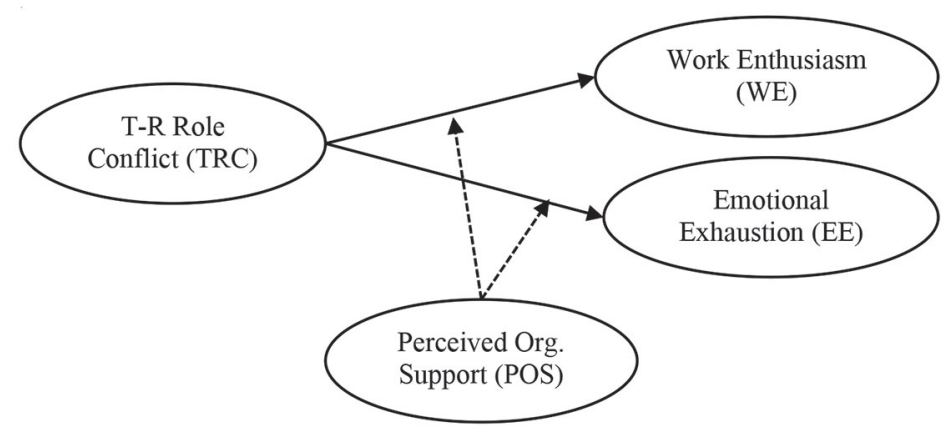

Figure 1. Research Model

\section{Method}

\section{Sample}

This study was conducted on 250 lecturers as a sample due to SEM analysis that requires a sample size of 150-400 (Hair, Black, Babin, \& Anderson, 2010). Still, only 233 responses were validated due to the sample requirements. The sample is taken randomly from nineteen large urban universities, and coming from five large islands in Indonesia. All selected samples must meet the requirements, conducting teaching and research activities for at least the last three years.

\section{Instruments}

We adapted five items (e.g. "the demands of my teaching interfere with my research," "due to teach-related duties, I have to make changes to my plans for research activities") from the work-family conflict scale (Netemeyer, Boles, \& McMurrian, 1996) to measure the teacher-researcher role conflict. We were also adopting six items (e.g., "teaching is 
fun for me," "I really enjoy teaching") from Aldrup, Klusmann, Lüdtke, Göllner, and Trautwein (2018) and Kunter et al. (2008) to measure work enthusiasm. Four items (e.g. "I sometimes feel really used up at the end of a school day," "I often notice how listless I am at school") from Maslach Burnout Inventory - Educators Survey (MBI-ES) (Maslach, Jackson, \& Leiter, 1997) to measure emotional exhaustion. Perceived organizational support was measured using seven items that adapted from the POS scale (Eisenberger, Huntington, Hutchison, \& Sowa, 1986). All the instruments are valid (loading factors $>0.7$ ), and reliable (alpha Cronbach >0.8) (Hair, Black, Babin, \& Anderson, 2010; Maholtra, 1996; Solimun, Fernandes, \& Nurjannah, 2017).

\section{Data Analysis}

We used structural equation modeling (SEM) in WarpPLS 6.0 to examine the research model. Before we test the research hypothesis, we conduct the goodness of fit test of our research model. The result indicates our research model is fit $(\mathrm{APC}<.001$; ARS $<.001$, $\mathrm{AVIF}=1.258, \mathrm{GoF}=.287$ (Solimun et al., 2017).

\section{Result and Discussion}

\section{Result}

The results of the 250 questionnaires given to the random sample, only 233 met the criteria, conducting teaching and research in at least the last three years. The result (table 1) shows that of the 233 samples, the majority were male (56\%) and female the rest (44\%). Meanwhile, the educational background of the sample is mostly masters (83\%) and holds doctorate degrees (17\%) for the rest.

Table 1

Respondents Characteristic $(N=233)$

\begin{tabular}{llcc}
\hline \multirow{2}{*}{ Gender } & & $\Sigma$ & $\%$ \\
\hline \multirow{2}{*}{ Educational Background } & Man & 131 & $56 \%$ \\
& Women & 102 & $44 \%$ \\
& Master & 193 & $83 \%$ \\
\cline { 2 - 3 } & Doctor & 40 & $17 \%$ \\
\hline
\end{tabular}

Table 2 shows us the mean, standard deviation, and correlation among the variable of this study. The result shows that TRC related to WE, EE, and POS. But WE did not relate to EE. 
Table 2

Mean, Standard Deviations and Correlation Among Variables $(N=233)$

\begin{tabular}{lccccccc}
\hline & Items & Mean & $\begin{array}{l}\text { Std. } \\
\text { Dev }\end{array}$ & TRC & WE & EE & POS \\
\hline TRC & 5 & 4.81 & 1.35 & - & & \\
WE & 6 & 4.62 & 0.41 & $-.40^{\star}$ & - & \\
EE & 4 & 4.67 & 1.24 & $.429^{\star *}$ & -.235 & - & \\
POS & 7 & 4.62 & 1.16 & $.693^{\star *}$ & $.437^{\star *}$ & $-.573^{\star *}$ & - \\
\hline
\end{tabular}

Note: ${ }^{\star} \mathrm{p}<0.05 ;{ }^{\star *} \mathrm{p}<0.01 ; \mathrm{TRC}=$ teacher-researcher role conflict, $\mathrm{WE}=$ work enthusiasm, $\mathrm{EE}=$ emotional exhaustion, $\mathrm{POS}=$ perceived organizational support

The analysis was run by WarpPLS to examine hypotheses 1 and 2 simultaneously. The result (figure 2) shows us that TRC has a negative effect on WE $(\beta=-.15, p<.01)$ and a positive effect on $\mathrm{EE}(\beta=.40, p<.01)$. Moreover, POS moderates the relation between TRC and WE $(\beta=.09, p=.03)$, also TRC and $\operatorname{EE}(\beta=-.12, p=.02)$.

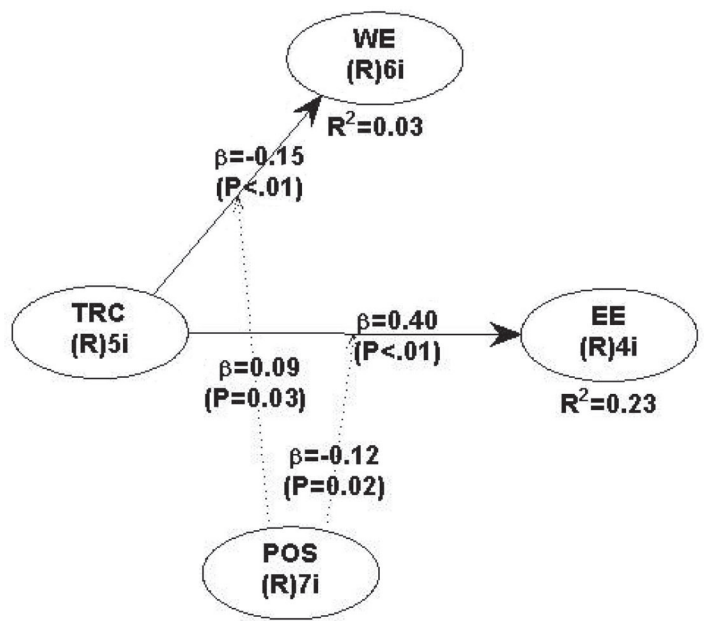

Figure 2. The output of data analysis

\section{General Discussion}

The result (figure 2) shows that teacher-researcher role conflict has a negative effect on work enthusiasm and a positive effect on emotional exhaustion. It indicates the teacher-researcher role conflict experienced by the lecturer not only reduces the work enthusiasm of lecturers but also raising emotional exhaustion. These are in line with the JD-R model. Job demands closely related to the psychological condition of the employee (Demerouti et al., 2001). This study also aligned with the scarcity model that employee with so many roles or task is easier to get role conflict (Moore, 1963) because of its drains energy, both physic and emotion. 
Also, the finding strengthens the personality model that states each job has a unique character that also requires a unique personality of employees (Eble, 1976). As mentioned in the theoretical framework, teaching and research have different characteristics; thus, it's hard to be good in two different jobs simultaneously. As a consequence, the dual role makes excessive workload of the lecturers and ultimately will reduce the work enthusiasm and increase emotional exhaustion. Besides, the divergent reward model that states each job has a different reward scheme (Ladd, 1979), its lead lecturer to focuses on the role that provides greater reward and neglect the others. It's mean the two roles (teacher and researcher) will lead the lecturer to the role conflict.

\section{Moderatio effect of POS}

The result shows that POS significantly moderated the link between role conflict and work enthusiasm, also between role conflict and emotional exhaustion. These also show us that POS play a positive moderating variable in the relationship between teacherresearcher role conflict, and a negative moderating variable between teacher-researcher role conflict and emotional exhaustion. The result indicates that POS, as job resources, reduce the negative impact of teacher-researcher role conflict on work enthusiasm and emotional exhaustion. Moreover, a lecturer with high POS reports high work enthusiasm and low emotional exhaustion - regardless of high role conflict.

This finding proved that POS is one of the job resources that reduce the negative impact of job demands. In this study, POS act as a moderating variable in reducing the negative effect of role conflict (Casper et al., 2002; Rhoades \& Eisenberger, 2002). The greater university support makes a lecturer feel recognized, valued, and feel worthy to carry out the dual role simultaneously, thereby reducing the negative effect of teacherresearcher role conflict that experiences by the lecturer on work enthusiasm and emotional exhaustion. Moreover, this study also declines the previous study, which stated that POS did not significantly moderate the link between teacher-researcher role conflict and emotional exhaustion (Xu, 2017). Our findings show that the higher POS, the lower the emotional exhaustion of the lecturer, regardless of the high role conflict that experienced. Furthermore, the present study successfully explained how the role of POS in reducing the negative impact of the teacher-researcher role of conflict on psychological well-being, which in previous studies was not clear.

This result also shows that university support is needed by a lecturer to carry out the high job demands, as a teacher and researcher. With the support, the lecturer feels recognized and valued for the efforts made to carry out the task well. Besides, university support is also felt like a form of organizational concern for the employees' condition, and ultimately increase work enthusiasm and reduce emotional exhaustion. It proves that POS can reduce the negative impact of teacher-researcher role conflict. The results also parallel with the previous studies which organizational support positively related to employee commitment and reduces the stress of role conflict, work attitude, and 
performance, mental health and lessen the effect of role conflict on work outcomes (Casper et al., 2002; Hao et al., 2016; Huang et al., 2007; Rhoades \& Eisenberger, 2002).

\section{Conclusion}

This study found that teacher-researcher role conflict significantly related to psychological well-being reduces work enthusiasm and increases emotional exhaustion. Besides, our study shows that perceived organizational support significantly plays a moderating role in the relation between teacher-researcher role conflict and psychological well-being. When the lecturer felt high POS, the negative effect of TRC on WE and EE will decrease. Finally, the university should pay more attention to reduces the negative effect of role conflict by providing better support to the lecturers.

This study provides several pieces of evidence that TRC and POS should be of concern to the university. First, the administrator might start thinking of how to reduce the job demands of lecturers, such as redesigning the structure of work by reducing the number of teaching hours and allowing lecturers to research according to their preferences. It aims to reduce the workload of lecturers that make strain so that it is expected to increase work enthusiasm and reduce emotional exhaustion. Second, the university is also expected to provide better organizational support by optimally providing lecturer needs. This will make the lecturer feel valued and supported by the institution and ultimately increase work enthusiasm and decrease emotional exhaustion.

\section{References}

Aldrup, K., Klusmann, U., \& Lüdtke, O. (2017). Does basic need satisfaction mediate the link between stress exposure and well-being. A diary study among beginning teacher. Learning and Instruction, 50, 21-30. doi:10.1016/j.learninstruc.2016.11.005

Aldrup, K., Klusmann, U., Lüdtke, O., Göllner, R., \& Trautwein, U. (2018). Student misbehavior and teacher well-being: Testing the mediating role of the teacher-student relationship. Learning and Instruction, 58, 126-136. doi:https://doi.org/10.1016/j.learninstruc.2018.05.006

Arens, A. K., \& Morin, A. J. S. (2016). Relations between teachers' emotional exhaustion and students' educational outcomes. Journal of Educational Psychology, 108(6), 800-813. doi:10.1037/edu0000105

Bakker, A. B., Demerouti, E., \& Euwema, M. C. (2005). Job resources buffer the impact of job demands on burnout. Journal of Occupational Health Psychology, 10(2), 170-180. doi:10.1037/1076-8998.10.2.170

Cao, C., Shang, L., \& Meng, Q. (2020). Applying the job demands-resources model to exploring predictors of innovative teaching among university teachers. Teaching and Teacher Education, 89, 1-9. doi:https://doi.org/10.1016/j.tate.2019.103009

Pedagogika / 2020, t. 138, Nr. 2 
Casper, W. J., Martin, J. A., Buffardi, L. C., \& Erdwins, C. J. (2002). Work-family onflict, perceived organizational support, and organizational commitment among employed mothers. Journal of Occupational Health Psychology, 7(2), 99-108.

Demerouti, E., Bakker, A. B., Nachreiner, F., \& Schaufeli, W. B. (2001). The job demandsresources model of burnout. Journal of Applied Psychology, 86(3), 499-512. doi:10.1037/00219010.86.3.499

Diener, E., Suh, E., Lucas, R. E., \& Smith, H. (1999). Subjective well-being: three decades of progress. Psychological Bulletin, 125(2), 276-302. doi:http://dx.doi.org/10.1037/ 00332909.125.2.276

Eble, K. (1976). The craft of teaching. New York: Jossey-Bass.

Eisenberger, R., Fasolo, P., \& Davis-LaMastro, V. (1990). Perceived organizational support and employee diligence, commitment, and innovation. Journal of Applied Psychology, 75(1), 51-59.

Eisenberger, R., Huntington, R., Hutchison, S., \& Sowa, D. (1986). Perceived organizational support. Journal of Applied Psychology, 71(3), 500-507.

Fernet, C., S. Austin, Trépanier, S. G., \& Dussault, M. (2013). How do job characteristics contribute to burnout? Exploring the distinct mediating roles of perceived autonomy, competence, and relatedness. European Journal of Work and Organizational Psychology 22(2), 123-137.

Hair, J. F., Black, W. C., Babin, B. J., \& Anderson, R. E. (2010). Multivariate data analysis (7th ed.) Upper Saddle River, NJ: Prentice Hall.

Hakanen, J. J., Bakker, A. B., \& Schaufeli, W. B. (2006). Burnout and work engagement among teachers. Journal of School Psychology, 43(6), 495-513. doi:10.1016/j.jsp.2005.11.001

Hao, J., Wang, J., Liu, L., Wu, W., \& Wu, H. (2016). Perceived organizational support impacts on the associations of work-family conflict or family-work conflict with depressive symptoms among chinese doctors. International Journal of Environmental Research and Public Health, 13(3). 1-13. doi:10.3390/ijerph13030326

Havighurst, R. J. (2018). Teaching. Retrieved from: https://www.britannica.com/topic/teaching Huang, Y., Fan, W., \& Fu, J. (2007). The work-family interface and job performance conscientiousness and perceived organizational support as moderators. Chin. J. Appl. Psychology, 13, 65-72.

Jencks, C., \& Riesman, D. (1968). The academic revolution. New York: Doubleday.

Kingman, J. (1993, June 1). The pursuit of truth. The Times Higher. London: TSL Education Ltd. Klusmann, U., Kunter, M., Trautwein, U., Lüdtke, O., \& Baumert, J. (2008). Teachers' occupational well-being and quality of instruction: The important role of self-regulatory patterns. Journal of Educational Psychology, 100(3), 702-715. doi:10.1037/0022-0663.100.3.702

Kunter, M., Tsai, Y.-M., Klusmann, U., Brunner, M., Krauss, S., \& Baumert, J. (2008). Students' and mathematics teachers' perceptions of teacher enthusiasm and instruction. Learning and Instruction, 18(5), 468-482. doi:10.1016/j.learninstruc.2008.06.008

Ladd, E. C. (1979). The work experiences of American college professors. Current Issues in Higher Education, 22, 135-154. 
Llorens, S., Schaufeli, W., Bakker, A., \& Salanova., M. (2007). Does a positive gain spiral of resources, efficacy beliefs and engagement exist? Computers in Human Behavior, 23(1), 825-841.

Maholtra, N. K. (1996). Marketing Research. London: Prentice-Hall International, Inc.

Maslach, C., Jackson, S. E., \& Leiter, M. P. (1997). Maslach Burnout Inventory.. In C. P. Zalaquett \& R. J. Wood (Eds.), Evaluating stress: A book of resources (3 rd. ed., pp. 191-218). Lanham, MD, US: Scarecrow Education.

Moore, W. (1963). Man, Time, and Society. New York: Wiley.

Netemeyer, R. G., Boles, J. S., \& McMurrian, R. (1996). Development and validation of workfamily conflict and family-work conflict scales. Journal of Applied Psychology, 81(4), 400-410. doi:10.1037/0021-9010.81.4.400

Parasuraman, S., Greenhaus, J. H., \& Granrose, C. S. (1992). Role Stressors, Social Support, and Well-Being Among TwoCareer Couples. Journal of Organizational Behavior, 13(4), 339-356.

Rafsanjani, M. A., Pamungkas, H., \& Rahmawati, E. D. (2019). Does teacher-student relationship mediate the relation between student misbehavior and teacher psychological well-being? JABE: Journal of Accounting and Business Education, 4(1), 34-44. doi:http://dx.doi.org/10.26675/jabe.v4i1.8411

Rafsanjani, M. A., \& Rahmawati, E. D. (2019). Stress Exposure and Psychological Well-being: Study on Beginning Teacher. JABE: Journal of Accounting and Business Education, 3(2), 162-169. doi:http://dx.doi.org/10.26675/jabe.v3i2.5757

Rhoades, L., \& Eisenberger, R. (2002). Perceived organizational support: A review of the literature. Journal of Applied Psychology, 87(4), 698-714.

Ryan, R. M., \& Deci, E. L. (2001). On happiness and human potentials: A review of research on hedonic and eudaimonic well-being. Annual Review of Psychology, 52(1), 141-166. doi:10.1146/ annurev.psych.52.1.141

Solimun, Fernandes, A. A. R., \& Nurjannah. (2017). Metode statistika multivariat pemodelan persamaan struktural (SEM) pendekatan WarpPLS. Malang: Universitas Brawijaya Press.

Van den Tooren, M., \& de Jong, J. (2014). Job demands-resources and employee health and wellbeing: The moderating role of contract type. Career Development International, 19(1), 101-122. doi:10.1108/CDI-05-2013-0058

Vigoda-Gadot, E., \& Meisler, G. (2010). Emotions in management and the management of emotions: The impact of emotional intelligence and organizational politics on public sector employees. Public Administration Review, 70(1), 72-86. doi:10.1111/j.1540-6210.2009.02112.x

Watson, D., Clark, L. A., \& Tellegen, A. (1988). Development and validation of brief measures of positive and negative affect: The PANAS scales. Journal of Personality and Social Psychology, 54(6), 1063-1070. doi:10.1037/0022-3514.54.6.1063

Wright, T. A., \& Cropanzano, R. (1998). Emotional exhaustion as a predictor of job performance and voluntary turnover. Journal of Applied Psychology, 83(3), 486-493. doi:https://doi. org/10.1037/0021-9010.83.3.486

Xanthopoulou, D., Bakker, A. B., Demerouti, E., \& Schaufeli, W. B. (2007). The role of personal resources in the job demands-resources model. International Journal of Stress Management 14(2), 121-141. 
$\mathrm{Xu}, \mathrm{L}$. (2017). Teacher-researcher role conflict and burnout among Chinese university teachers: a job demand-resources model perspective. Studies in Higher Education, 44(6), 903-919. doi:10.1080/03075079.2017.1399261

\section{Suvokiamas organizacinis palaikymas ir mokytojo-tyrejo neigiamo vaidmens konflikto poveikio dèstytojams sumažinimas: tyrimo Indonezijoje duomenys}

Mohamad Arief Rafsanjani ${ }^{1}$, Muhammad Abdul Ghofur ${ }^{2}$, Dhiah Fitrayati ${ }^{3}$, Retno Mustika Dewi ${ }^{4}$

Negeri Surabaja universitetas, Ekonomikos fakultetas, Jl. Ketintang, Surabaja, Indonezija, mohamadrafsanjani@unesa.ac.id Negeri Surabaja universitetas, Ekonomikos fakultetas, Jl. Ketintang, Surabaja, Indonezija, muhammadghofur@unesa.ac.id Negeri Surabaja universitetas, Ekonomikos fakultetas, Jl. Ketintang, Surabaja, Indonezija, dhiahfitrayati@unesa.ac.id

Negeri Surabaja universitetas, Ekonomikos fakultetas, Jl. Ketintang, Surabaja, Indonezija, retnomustika@unesa.ac.id

\section{Santrauka}

Dėstytojui vienu metu reikia būti ir mokytoju, ir tyrèju, taip susidaro pernelyg didelis krūvis. Kaip nurodoma literatūros šaltiniuose, kiekvienam žmogui yra sunku vienu metu suderinti per daug vaidmenų ir tinkamai juos atlikti. Be to, tuo pačiu metu atliekant per daug vaidmenų, yra daug galimybių patirti vaidmenų konfliktus dèl laiko ir energijos trūkumo. Ankstesni tyrimai rodo, kad vaidmens konfliktas kenkia psichologinei savijautai. Tyrimo tikslas - ištirti, kaip galima sušvelninti neigiamą vaidmens konflikto poveikị tarp tyrèjo ir dèstytojo. Remiantis darbo poreikių-išteklių modeliu, matyti, kad darbo ištekliai sumažina neigiamą darbo poreikių poveikị. Atsižvelgiant ị ankstesnių tyrimų išvadas, suvokiamas organizacinis palaikymas (angl. perceived organizational support) yra priskiriamas prie darbo išteklių ir nagrinejjamas kaip moderuojamas kintamasis, kuris sumažina mokytojo-tyrėjo vaidmens konflikto poveikị ir pagerina psichologinę savijautą.

Gauti rezultatai atskleidžia, kad nepaisant didelio vaidmens konflikto dėstytojų, turinčių aukštą suvokiamo organizacinio palaikymo rodiklị, žymiai geresnè psichologinè savijauta. Siūloma universitetams stiprinti suvokiamą organizacinị palaikymą, kad būtų sumažintas neigiamas mokytojo-tyrèjo vaidmens konflikto poveikis.

Esminiai žodžiai: suvokiamas organizacinis palaikymas, mokytojo-tyrëjo vaidmens konfliktas, psichologinè savijauta, dèstytojas. 